\title{
Landscape heterogeneity and the use of space by elephants in the Kruger National Park, South Africa
}

\author{
Matthew Grainger ${ }^{1}$, Rudi van Aarde ${ }^{1, *}$ and Ian Whyte ${ }^{2}$ \\ ${ }^{1}$ Conservation Ecology Research Unit, Department of Zoology and Entomology, University of Pretoria, Pretoria 0002, South Africa and ${ }^{2}$ South \\ African National Parks, Kruger National Park, Private Bag X402, Skukuza 1250, South Africa
}

\begin{abstract}
Landscape heterogeneity may influence ranging behaviour of mammals. Here we relate the home range size of elephants living in the Kruger National Park to the number of patches, proportion of each patch, spatial arrangement of patches, patch shape, and contrast between neighbouring patches. Home range sizes decreased exponentially with an increase in the number of patches per $100 \mathrm{~km}^{2}$ and the home range sizes of bulls were in general more strongly related to measures of heterogeneity. This may reflect differences in perception of heterogeneity between the sexes.

Key words: FRAGSTATS, home range, landscape heterogeneity
\end{abstract}

\section{Résumé}

Il se peut que la hétérogénéité du paysage agisse sur le comportement des mammifères au pâturage. Dans cette étude nous associons la taille des domaines vitaux des éléphants résidant dans le Parc National de Kruger au nombre de parcelles et leurs dimensions, disposition spatiale et forme, ainsi que le contraste entre des parcelles avoisinantes. La taille des domaines vitaux diminua exponentiellement avec l'augmentation dans le nombre de parcelles par $100 \mathrm{~km}^{2}$ alors que les domaines vitaux des mâles furent plus fortement associés aux mesures d'hétérogénéité en général. Cela est peut être dû aux différences au niveau de la perception d'hétérogénéité entre les sexes.

\section{Introduction}

The availability of resources including nutrients, food, cover (Tufto, Andersen \& Linnell, 1996), and water (Stokke \& du Toit, 2002) may account for the intra-specific

*Correspondence: E-mail: rjvaarde@zoology.up.ac.za variation in home range sizes of mammals. The age (Cederlund \& Sand, 1994), sex (Relyea, Lawrence \& Demarais, 2000) and reproductive status (Bertrand et al., 1996) of individuals may also influence home range areas. Resource requirements underpin these factors and the distribution of resources across landscapes may therefore influence the size of home ranges. Resource distribution is rarely homogeneous, as the environment is made up of a mosaic of patches (Wiens, 1989). This patchiness at the landscape scale is referred to as landscape heterogeneity.

The use of landscape metrics to quantify landscape heterogeneity is currently open to misinterpretation (Fortin et al., 2003). By considering landscape heterogeneity within the area of an individual's home range, the potential exists to become entwined in a circular argument (Kie et al., 2002) - do animals select their home ranges for a certain level of heterogeneity, or is a certain level of heterogeneity caught within a home range size determined by another factor? This argument probably can only be fully resolved by observing relationships at different spatial scales.

Elephants roam across a wide range of landscapes over African savannas. Individual home ranges may include a variety of landscapes and vary, both within and between populations. For example in Etosha National Park home ranges may be as large as $7250 \mathrm{~km}^{2}$ (Lindeque \& Lindeque, 1991), but those in Lake Manyara National Park cover only $33 \mathrm{~km}^{2}$ (Douglas-Hamilton, 1972). In this study we address this variability by investigating the contribution landscape heterogeneity may make to the variability in home range size of elephants in the Kruger National Park (KNP). Here home ranges varied from 45 to $1805 \mathrm{~km}^{2}$ (Whyte, 2001). We are not aware of any earlier studies that have addressed the influence of landscape heterogeneity for home range in elephants. Landscape heterogeneity may explain variability in habitat selection (Crist et al., 1992; Boyce et al., 2003) and we therefore expect that measures of heterogeneity may explain variation in home range variables in elephants. 


\section{Materials and methods}

Study area

The KNP is situated in the northeast of South Africa and extends over $18,992 \mathrm{~km}^{2}$ (Whyte, van Aarde \& Pimm, 2003). It lies between $22^{\circ} 20^{\prime}$ to $25^{\circ} 32^{\prime} \mathrm{S}$ and $30^{\circ} 53^{\prime}$ to $32^{\circ} 02^{\prime} \mathrm{E}$. Gertenbach (1983) recognized 35 landscapes within the park based on plant communities, climate, soil type, and geology.

\section{Home range analysis}

We used data collected in two separate radiotelemetry studies on elephant movements within the KNP. Dr Anthony Hall-Martin collected data on elephant bulls from 1976 to 1992, and Dr Ian Whyte collected cow data from 1989 to 1996 (Whyte, 2001). These data were collected from 37 bulls and 50 cows. RANGES 6 (Anatrack Ltd., Wareham, UK) software was used to estimate home ranges using 95\% minimum convex polygon estimator. This estimator has the ability to make better use of small amounts of data and is the only estimator that can be compared across studies (White \& Garrott, 1990). Home ranges were separated by gender and season (wet season: September to April; dry season: May to August).

To determine how many fixes were needed to reach an asymptotic home range size, we plotted the percentage of the total home range size against the number of fixes. For illustrative purposes a one-phase exponential association curve was fitted to these data using GraphPad Prism Version 3.00 (Graph Pad Software Inc., San Diego, California, USA). To determine the starting point of asymptote we used a two-phase linear regression model (see Fox et al., 1997). Differences in home range between sexes were tested using a Mann-Whitney U-test.

We superimposed home ranges on to a landscape map of the Park and on maps depicting the distribution of natural water sources (rivers, springs, and pans) across the Park (available from SANParks) using the facilities of ArcView Version 3.3. (Environmental Systems Research Institute Inc., Redlands, California, USA).

\section{Landscape heterogeneity analysis}

Within home ranges we measured eight landscape variables using the raster version of FRAGSTATS (Version 3.3, McGarigal \& Marks, 1995). FRAGSTATS expresses metrics as both absolute and relative measures. We used relative measures to compare heterogeneity across different home range sizes. For example, patch richness (the number of patches in a landscape or map) is of no use when comparing home ranges of different sizes and consequently we used patch richness density (the number of patches in a landscape or map per square kilometre). Those metrics that best described at least one facet of $\mathrm{Li} \&$ Reynolds (1994) five descriptive variables of landscape heterogeneity were chosen (Table 1). In this study a patch was defined as an area of one landscape type surrounded by other landscape types or delimited by the home range boundary.

Table 1 Summary of the metrics used to quantify landscape heterogeneity, adapted from McGarigal \& Marks (1995)

\begin{tabular}{|c|c|c|}
\hline Descriptor of landscape heterogeneity & Landscape metrics & Description of measurement \\
\hline Number of patches & Patch richness density & $\begin{array}{l}\text { Measures the number of patches in a landscape map but accounts for } \\
\text { overall area. Expressed as number of patches per } 100 \mathrm{~km}^{2}\end{array}$ \\
\hline Proportion of each patch & Largest patch index & Measures the percentage of the total area comprised by the largest patch \\
\hline \multirow[t]{3}{*}{ Spatial arrangement of patches } & Cohesion & Measures the spatial distribution of patch types. Expressed as percentage \\
\hline & Contagion & $\begin{array}{l}\text { Measures the intermixing of different patch types in a landscape map. } \\
\text { Expressed as a percentage }\end{array}$ \\
\hline & $\begin{array}{l}\text { Euclidean nearest } \\
\text { neighbour distance }\end{array}$ & $\begin{array}{l}\text { Measures in } \mathrm{km} \text { the distance to the next patch of the same type as the } \\
\text { focal patch }\end{array}$ \\
\hline \multirow[t]{2}{*}{ Patch shape } & Mean shape index & $\begin{array}{l}\text { Compares the complexity of the patch shape with a simple shape (circle) } \\
\text { Expressed as a ratio between number of cells in the patch and the } \\
\text { number of cells needed to create a circle }\end{array}$ \\
\hline & Edge density & $\begin{array}{l}\text { Measures the total edge between patches divided by total area. } \\
\text { Expressed as km per } 100 \mathrm{~km}^{2}\end{array}$ \\
\hline $\begin{array}{l}\text { Contrast between } \\
\text { neighbouring patches }\end{array}$ & Mean edge contrast & $\begin{array}{l}\text { Measures the degree of user-defined contrast between patches. } \\
\text { Expressed as percentage contrast }\end{array}$ \\
\hline
\end{tabular}


For the mean edge contrast metric FRAGSTATS allows the user to specify contrast between landscape types. Contrast is scored on a scale of $0-1$, with 0 being the minimum and 1 being the maximum contrast. A contrast score was assigned to each landscape type after Gertenbach's (1983) landscapes were reclassified into mountainous landscapes, thicket landscapes, woody vegetation landscapes and open tree savannah landscapes. The highest level of contrast was considered to be between mountain landscapes and the other landscapes and assigned a level of 0.9. Less contrast was considered between thicket and woody vegetation landscapes and assigned a score of 0.4 (Table 2). The relationship between home range size and each metric was tested using either linear or nonlinear regression analyses.

\section{Results}

\section{Elephant home range}

Bulls had clearly defined home ranges (i.e. the areas reached an asymptote) after 30 location fixes in the dry season $(n=37)$ and 40 location fixes in the wet season $(\mathrm{n}=34)$. Data for 33 bulls in the dry season and 27 bulls in the wet season were excluded from further analyses because of insufficient data. Cows had clearly defined home ranges after eighteen locations in the dry season $(\mathrm{n}=49)$ and 40 locations in the wet season $(\mathrm{n}=$ 50). Data for 38 cows in the dry season and 42 cows in the wet season were not analysed because of insufficient data.

Total home range size ranged between 72 and $4451 \mathrm{~km}^{2}$ (mean $\left.\pm \mathrm{SD}=988 \pm 991 \mathrm{~km}^{2}, \mathrm{n}=26\right)$ and was not affected by sex ( $P>0.05$; Mann-Whitney $U$-test). Season also had no influence on the range sizes of bulls and cows $(P>0.05$ Mann-Whitney $U$-test).
Landscape heterogeneity

Home range sizes for both sexes and in both seasons (bulls: $\mathrm{n}=10, r^{2}=0.84$; cows: $\mathrm{n}=16, r^{2}=0.82$; Fig. 1 ; bulls: dry season, $\mathrm{n}=4, r^{2}=0.99$, wet season, $\mathrm{n}=7, r^{2}=$ 0.96; cows: dry season, $\mathrm{n}=11, r^{2}=0.74$, wet season, $\mathrm{n}=8, r^{2}=0.61$; Fig. 2) declined exponentially with an increase in landscape patch richness density (number of landscape patches per $100 \mathrm{~km}^{2}$ ).

Home range size also declined exponentially as a function of natural water source richness for the bulls in the wet season $\left(\mathrm{n}=7, r^{2}=0.99\right)$, cows in the dry season ( $\left.\mathrm{n}=11, r^{2}=0.59\right)$ and cows in the wet season $(\mathrm{n}=8$, $\left.r^{2}=0.69\right)$. Ranges for bulls in the dry season showed no relationship with natural water source richness.

Landscape patch index was significantly negatively related to home range size in cows and to cows in the wet season. Percentage contagion was significantly positively related to home range size for bulls, and to bull ranges in the dry and wet season. Bull ranges in the wet season were also significantly positively related to percentage cohesion. Cow home range and bull range in the wet season showed a significant positive relationship to mean shape index. Edge density was significantly negatively related to home range for bulls and to bulls in the wet season. There was a significant positive relationship to mean edge contrast for bulls (see Table 3 for summary of results).

\section{Discussion}

Home range sizes vary within mammal species (Franklin et al., 1999; Whyte, 2001; Kie et al., 2002). For elephants the home ranges of bulls tends to be larger than those of cows (Viljoen, 1989; Stokke \& du Toit, 2002). This may partly be attributed to sexually mature bulls roaming large distances in search of oestrous cows. Another factor may be the restriction juvenile elephants place on the ability of
Table 2 Edge contrast weights between landscapes. Contrast was scored between 0 and 1 , with 1 being the maximum contrast

\begin{tabular}{|c|c|c|c|c|}
\hline $\begin{array}{l}\text { Landscape } \\
\text { classification }\end{array}$ & $\begin{array}{l}\text { Mountain } \\
\text { landscape }\end{array}$ & $\begin{array}{l}\text { Thicket } \\
\text { landscape }\end{array}$ & $\begin{array}{l}\text { Woody vegetation } \\
\text { landscape }\end{array}$ & $\begin{array}{l}\text { Open tree savannah } \\
\text { landscape }\end{array}$ \\
\hline Mountain landscape & 0 & 0.9 & 0.9 & 0.9 \\
\hline Thicket landscape & 0.9 & 0 & 0.4 & 0.6 \\
\hline $\begin{array}{l}\text { Woody vegetation } \\
\text { landscape }\end{array}$ & 0.9 & 0.4 & 0 & 0.4 \\
\hline $\begin{array}{l}\text { Open tree savannah } \\
\text { landscape }\end{array}$ & 0.9 & 0.6 & 0.4 & 0 \\
\hline
\end{tabular}


(a)

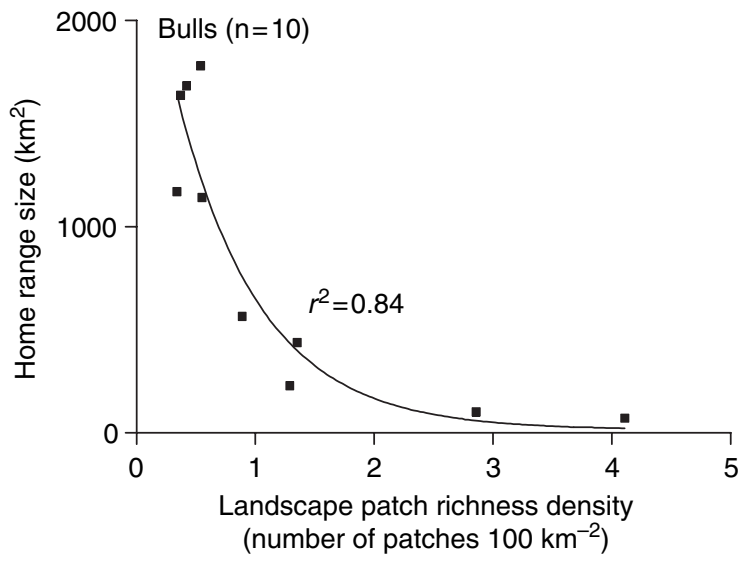

(b)

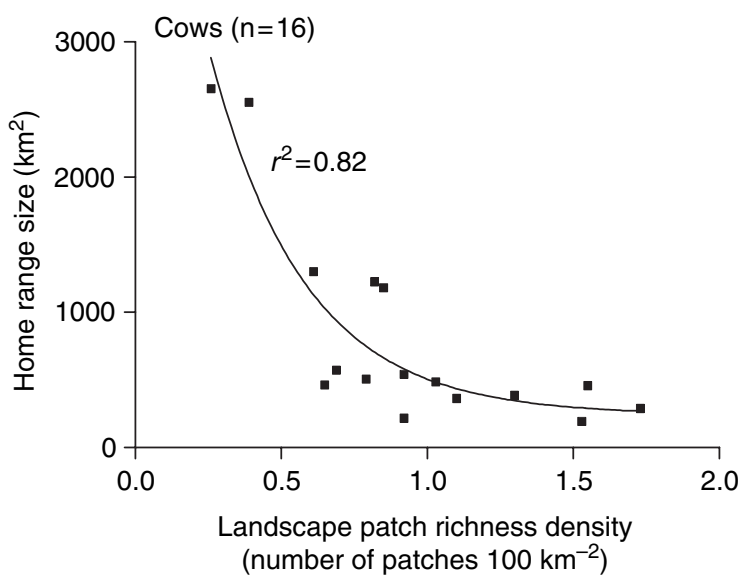

Fig 1 The relationship between 95\% minimum convex polygon home range size $\left(\mathrm{km}^{2}\right)$ and landscape patch richness density for (a) bulls and (b) cows. For illustrative purposes a one-phase exponential association curve has been fitted to these data

breeding herds to travel away from water, because of mortality (Barnes, 1983).

In our study, we did not find a significant gender difference in the home range size. The complete fencing of the KNP may prevent bulls from moving the large distances that are seen in unfenced populations. Water sources within Kruger are positioned less than $10 \mathrm{~km}$ apart (Thrash, 1998) so water may not limit the movement of breeding herds (Barnes, 1983; Viljoen, 1989).

Home range in elephants generally increases in the wet season, possibly as water availability increases (Stokke \& $\mathrm{du}$ Toit, 2002). This was not, however, the case in the
KNP. Here the availability of artificially maintained perennial water sources might negate these differences. Unfortunately, the lack of chronological information on the history of these sources did not allow us to assess their impact on ranging behaviour.

Variation in home range size is perhaps best related to the resource requirements of individual animals (Harestad \& Bunnell, 1979). The spatial distribution of resources will therefore influence home range. Theoretically we would expect an animal foraging in a patchy environment to decrease its home range size with an increase in resource availability (Ford, 1983).

Elephants in the Kruger may reduce their home range size in response to increasing landscape patch richness density. The variability this factor explains in cow range size is, however, less than for bulls. We argue this may be ascribed to cows being affected by processes that operate at different scales than bulls, as spatial and temporal scales affect movement decisions of animals (Ims, 1995). This is because of different life processes (that lead to movement) being manifested at different scales (Ims, 1995). As female reproductive success may be closely linked to resources (Gehrt \& Fritzell, 1998), cow elephants may be selecting at a scale that is more directly related to resource acquisition.

The availability of water sources is a major determinant of home range size for water-dependent mammals (Viljoen, 1989; Ordway \& Krausman, 1986). Stokke \& du Toit (2002) showed that elephant family groups in Chobe National Park, Botswana, did not move further than $3.5 \mathrm{~km}$ from rivers in the dry season and $5 \mathrm{~km}$ in the wet season. Bull and cow home range size in our study declined exponentially with an increase in water source patch richness density. This indicates that elephants in areas of high water point richness density have smaller home ranges than those in areas with low water point richness density. This has implications for conservation managers, as an increased density of water sources could reduce home range area and increase the intensity of patch use within a home range.

The ecological importance of edges has been widely studied because of the increased fragmentation of habitats. Tufto et al. (1996) suggest that edges are one of the most important landscape attributes influencing home range size. If complementary resources are adjacent to each other, animals should spend more time on the edge of resource patches in order to maximize the availability of these neighbouring resources, and subsequently increase 
Fig 2 The relationship between 95\% minimum convex polygon home range size $\left(\mathrm{km}^{2}\right)$ and landscape patch richness density for bulls in the (a) dry season, (b) wet season and cows in the (c) dry season and (d) wet season. For illustrative purposes a one-phase exponential association curve has been fitted to these data (a)

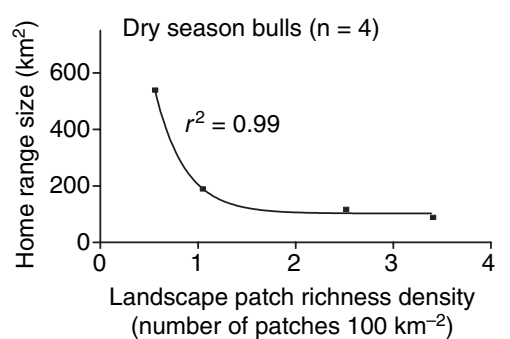

(c)

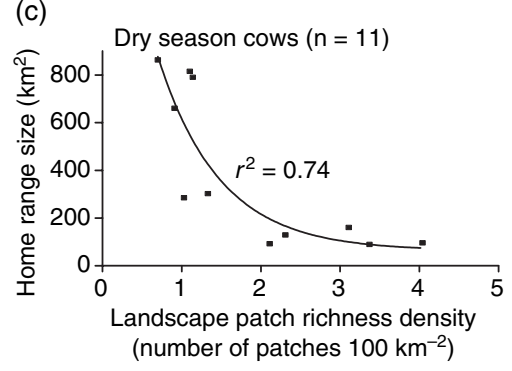

(b)

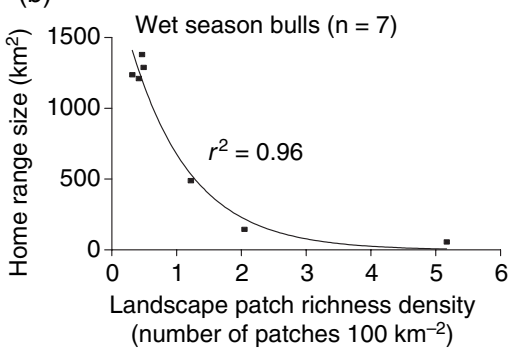

(d)

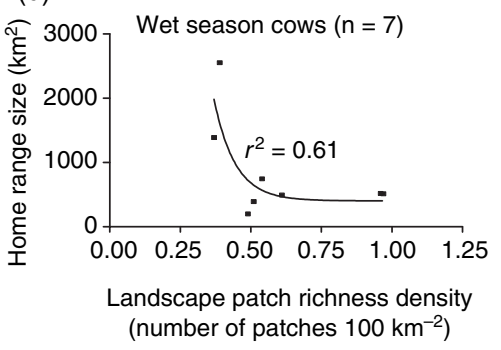

habitat heterogeneity (Tufto et al., 1996). Therefore, as more edges become available we would expect home range size to decrease (Tufto et al., 1996; Kie et al., 2002). During the wet season elephant bull ranges decreased with increasing edge density, while those of cows increased with increasing edge density. This is difficult to interpret.

Patch shape is also a measure of edge as an irregular patch has more edge. Elephants in the KNP did not appear to select for irregular shaped patches; there was a weak positive relationship for cows and a stronger positive relationship for bull ranges and patch shape in the wet season. The fact that these two relationships are positive suggests that this is not an ecologically significant relationship.

Our measures of edge may be affected by the boundaries that Gertenbach (1983) produced when delineating the Park's landscape types. At the landscape scale landscape types may not represent complementary resources for cow elephants. Cows may be selecting home range variables at a finer scale of heterogeneity than the landscape maps we used allows, given that this is the scale at which foraging decisions take place (Ims, 1995). It appears that, to some extent, bull elephants do select home range size in relation to edge at the landscape scale. Thus, the two sexes may perceive landscape heterogeneity differently.

The percentage edge contrast was only significantly related to range size in bull elephants. This relationship was positive whereas we would expect it to be negative. The more contrast between patches that are close together, the more resources that are available (Dunning, Danielson \& Pulliam, 1992). The lack of any relationship for cows, and for bulls in the dry season suggests that elephants do not perceive contrast between landscape patches in the same way that we assessed them.

None of the metrics we considered reacted in the same way to all conditions (bull, cow, wet season, dry season), which suggests that the metrics were not merely displaying an area relationship, increasing or decreasing as home range size increased. This has been a concern in other studies of this nature (Kie et al., 2002).

We have shown that home range size in elephants, more particularly bulls, is related to certain measures of landscape heterogeneity. Furthermore, we showed that the availability and distribution of natural water sources is a strong determinant of home range size of elephants. The artificial manipulation of water sources in Kruger may influence home range size, influencing the effects of elephants on vegetation within their ranges.

\section{Acknowledgements}

The National Research Foundation and the South African National Parks funded this project. The study benefited from inputs by Drs Anthony Hall-Martin and Tim Jackson. 


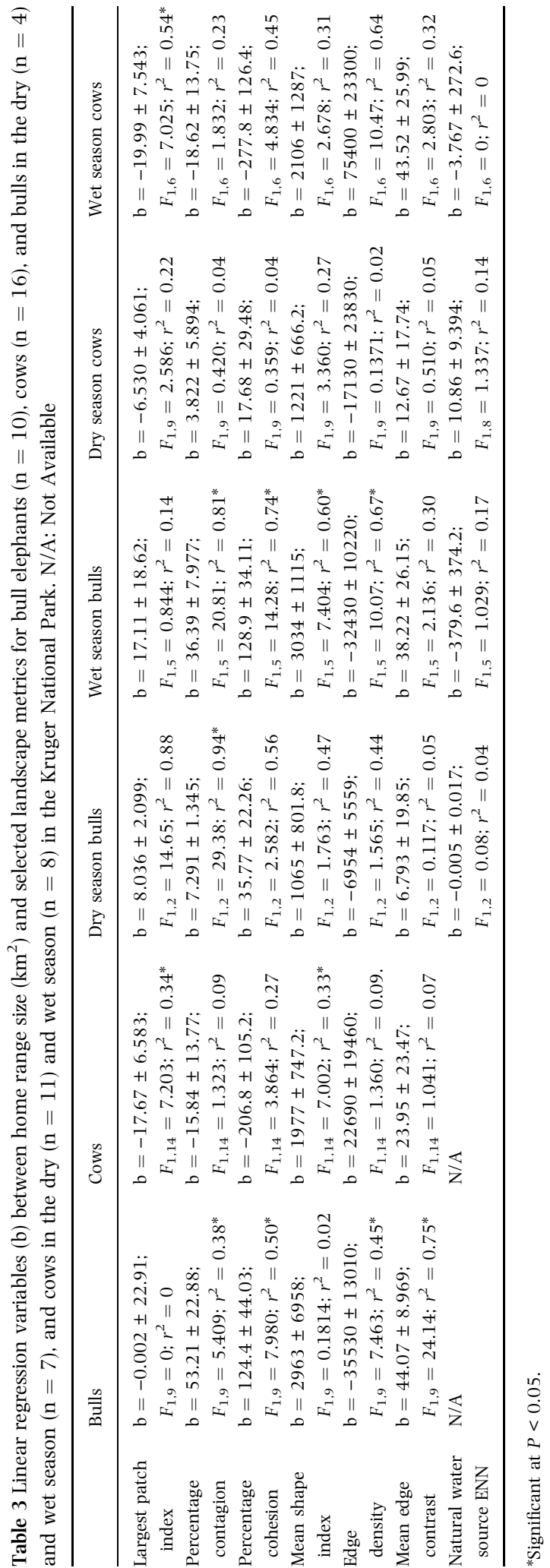

\section{References}

BARNES, R.F.W. (1983) Elephant behaviour in a semi-arid environment. Afr. J. Ecol. 29, 185-196.

Bertrand, M.R.A., Denicola, A.J., Beissinger, S.R. \& Swilhart, R.K. (1996) Effects of parturition on home ranges and social affiliations of female white-tailed deer. J. Wildl. Manage. 60, 899-909.

Boyce, M.S., MAO, J.S., MerRILL, E.H., Fortin, D., Turner, M.G., FryXell, J. \& Turchin, P. (2003) Scale and heterogeneity in habitat selection by elk in Yellowstone National Park. Ecoscience 10, 421-431.

Cederlund, G. \& SAND, H. (1994) Home-range size in relation to age and sex in moose. J. Mammal. 75, 1005-1012.

Crist, T.O., Guertin, D.S., Wiens, J.A. \& Milne, B.T. (1992) Animal movement in heterogeneous landscapes: an experiment with Eleodes beetles in shortgrass prairie. Funct. Ecol. 6, 536-544.

Douglas-Hamilton, I. (1972) On the ecology and behaviour of the African elephant. DPhil Thesis, Oxford University, Oxford.

Dunning, J.B., Danielson, B.J. \& Puluiam, H.R. (1992) Ecological processes that affect populations in complex landscapes. Oikos 65, 169-175.

FoRD, R.G. (1983) Home range in a patchy environment: optimal foraging predictions. Am. Zool. 23, 315-326.

Fortin, M.J., Boots, B., Csillag, F. \& Remmel, T.K. (2003) On the role of spatial stochastic models in understanding landscape indices in ecology. Oikos 102, 203-212.

Fox, B.J., TAYloR, J.E., Fox, M.D. \& Williams, C. (1997) Vegetation changes across edges of rainforest remnants. Biol. Conserv. 82, $1-13$.

Franklin, W.L., Johnson, W.E., Sarno, R.J. \& Iriarte, J.A. (1999) Ecology of the Patagonian puma Felis concolor patagonica in Southern Chile. Biol. Conserv. 90, 33-40.

GeHRT, S.D. \& FritzelL, E.K. (1998) Resource distribution, female home range dispersion and male spatial interactions: group structure in a solitary carnivore. Anim. Behav. 55, 12111227.

GERTENBACH, W.P.D. (1983) Landscapes of the Kruger National Park. Koedoe 26, 9-122.

Harestad, A.S. \& BunnelL, F.L. (1979) Home range and body weight - a reevaluation. Ecology 60, 389-402.

IMs, R.A. (1995) Movement patterns related to spatial structures. In: Mosaic Landscapes and Ecological Process (Eds L. HAnsson, L. FAHrig and G. MERriam). Chapman \& Hall, London.

Kie, J.G., Bowyer, R.T., Nicholson, M.C., Boroski, B.B. \& Loft, E.R. (2002) Landscape heterogeneity at differing scales: Effects on spatial distribution of mule deer. Ecology 83, 530-544.

LI, H. \& ReYNoLDS, J.F. (1994) A simulation experiment to quantify spatial heterogeneity in categorical maps. Ecology 75, 24462455.

LindeQue, M. \& LindeQue, P.M. (1991) Satellite tracking of elephants in North Western Namibia. Afr. J. Ecol. 29, 196206.

McGarigal, K. \& MARKs, B.J. (1995) FRAGSTATS: Spatial Pattern Analysis Program for Quantifying Landscape Structure. USDA for Sov. Gen. Tech. Rep. PNW-351. 
Ordway, L.L. \& Krausman, P.R. (1986) Habitat use by desert mule deer. J. Wildl. Manage. 50, 677-683.

ReLYeA, R.A., LAWRence, R.K. \& Demarais, S. (2000) Home range of desert mule deer: testing the body-size and habitat-productivity hypotheses. J. Wildl. Manage. 64, 146-153.

Sтокке, S. \& du Torт, J.T. (2002) Sexual segregation in habitat use by elephant in Chobe National Park, Botswana. Afr. J. Ecol. 40, 360-371.

Thrash, I. (1998) Impact of water provision on herbaceous vegetation in Kruger National Park, South Africa. J. Arid. Environ. 38, 437-450.

Tufto, J., Andersen, R. \& Linnell, J. (1996) Habitat use and ecological correlates of home range size in a small cervid: the roe deer. J. Anim. Ecol. 65, 715-724.

VILJoEn, P.J. (1989) Spatial distribution and movements of elephants (Loxodonta africana) in the Northern Namib Desert Region of the Kaokoveld, South West Africa/Namibia. J. Zool., (Lond.) 219, 1-19.
White, G.C. \& GarrotT, R.A. (1990) Analysis of Wildlife RadioTracking Data. Academic Press, New York.

WhYTE, I.J. (2001) Conservation management of the Kruger National Park Elephant population. PhD Thesis, University of Pretoria, Pretoria.

Whyte, I.J., van Aarde, R.J. \& Pimm, S. (2003) Kruger National Park's elephant population: its size and consequences for ecosystem heterogeneity. In: The Kruger Park Experience: Ecology and Management of Savanna Heterogeneity (Eds J. T. Du Torт, H. C. Biggs and K. H. Rogers). Island Press, Washington.

Wiens, J.A. (1989) The Ecology of Bird Communities (Volume 2), Processes and Variations. Cambridge University Press, Cambridge.

(Manuscript accepted 12 July 2005) 